\title{
Braceros: Migrant Citizens and Transnational Subjects in the Postwar United States and Mexico
}

Deborah Cohen, 2011, Chapel Hill, United States, The University

of North Carolina Press, 328 pp.

Torrie HESTER

Saint Louis University

Deborah Cohen has written an insightful book on the Bracero Program, the unofficial name for the series of labor exchange agreements between Mexico and the United States that lasted from 1942 to 1964 . Nearly two million Mexican men worked temporarily in the United States as braceros. Concentrating on the Mexican state of Durango and the Imperial Valley of California, Cohen's monograph incorporates the voices of the diverse program participants, ranging from the braceros and other domestic farm workers in the United States to the leaders and members of agricultural labor unions, growers and their foremen, government officials and Catholic priests. Braceros is a critical study of the interactions between labor, race, transnational migration, and nation-building that helped transform the meaning of the U.S.-Mexico border in the postwar period.

Braceros is organized into three sections that tell a sophisticated, at times heart-wrenching history. Section one, "Producing Transnational Subjects" situates the program and braceros in the larger historical context on both sides of the U.S.-Mexico border. Section two, "Bracero Agency and Emergent Subjectivities", opens with material from Cohen's many oral interviews with braceros: "One warm afternoon, Álvaro García told the crew in the barbershop how proud he was to have been selected [for the Bracero Program]. 'I was proud, too' said Ramón Avitia. State officials, '...told us we would teach the Americans about Mexico, that we'd bring progress to Mexico, to Durango"' 
(p. 89). In this section, Cohen recounts the experiences and subjectivities of braceros like Garcia and Avitia. The reader does not see as deeply into the lives of the women and families left behind in Durango, but Braceros' analysis of the meaning of patriarchy in explaining why the men left and the legacy of the program are important contributions to the study of gender. In the final section, "The Convergence of Elite Alliances", Cohen explores the question of whether the program was one of opportunity or exploitation and the relationship of "progress" to both. It leads the reader to further understand the importance of the Bracero Program in larger issues of state formation and the transnationalism.

Cohen frames the history of the Bracero Program around the concept of the modern, "the then broadly accepted term for the ideological package that figured progress, democracy, and technological and scientific advancement as unquestionable goals" (p. 3). Using this concept as a frame, Cohen's book contributes to a number of historical fields. For those interested in the history of the Mexican state; Braceros makes the provocative case that as the Mexican government proved unable to address the needs of its migrant citizens, braceros "acted in the interests of themselves and their families, weakening the state's leverage, from which they would have benefited significantly. That is, the braceros' actions steadily wrote the state out of its own national story" (p. 219). For those interested in farm labor and business history, Cohen notes that the Bracero Program represented a source of federal support for U.S. growers, helping to explain the enormous success of California agribusiness and the eventual termination of the Bracero Program. Cohen writes: "This support came in two forms: first, allowing growers to employ and control low-wage labor, from which they accumulated capital for equipment and additional land ... and second, funding research on seed and soil requirements for sustained mechanized farming". She continues: "only after these technologies were readily available at reasonable cost (in the 1960s) would the Bracero Program be terminated" (pp. 39-40).

As a whole, Braceros will be of great use to scholars and students interested in the histories of Mexico and the United States, gender and masculinity, race and class, border studies and western history, state formation and transnationalism. 